Asta $80 \% 8$
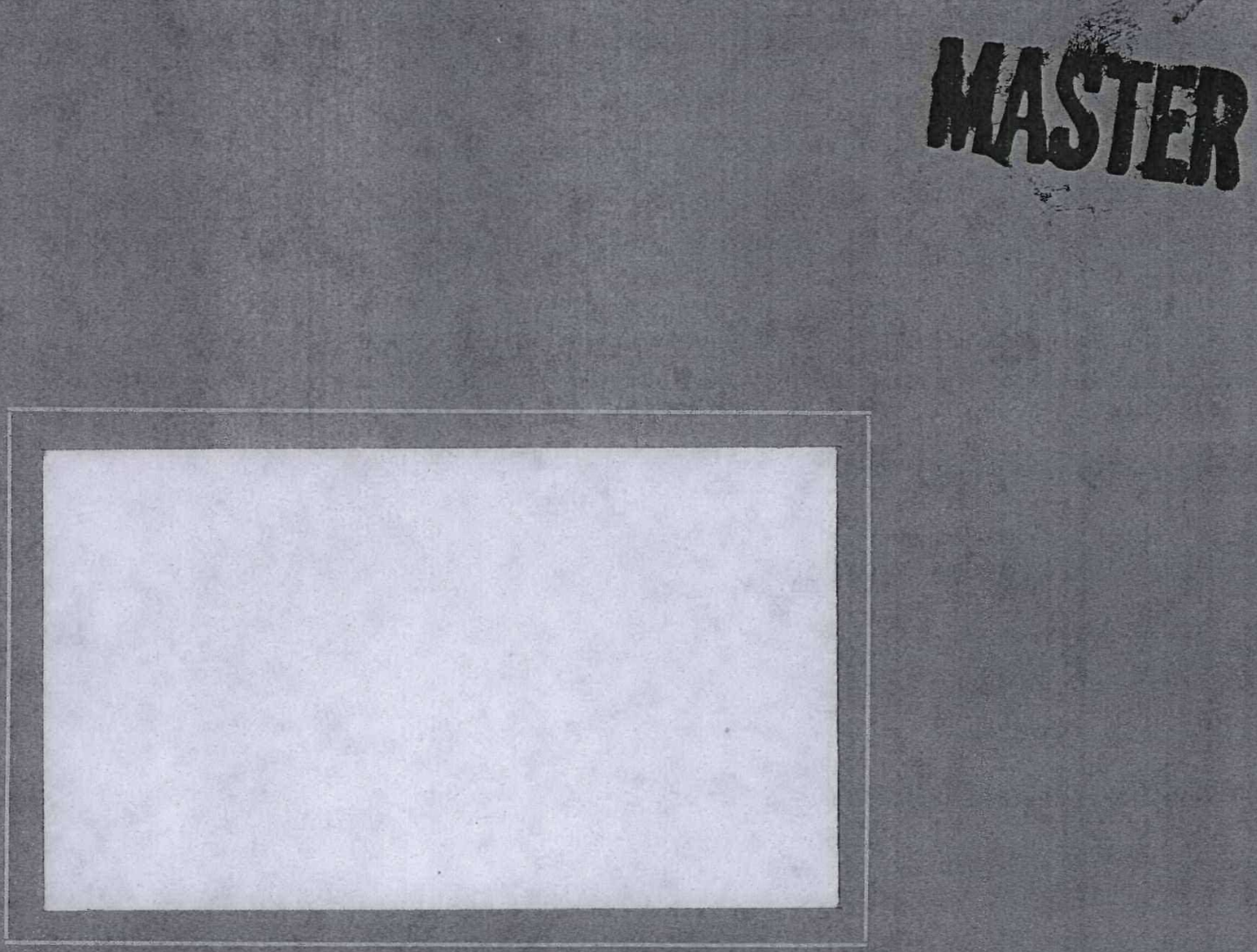

REIEASED FOR ANNOUNCEMENT

IN NUCLEAR SCIENCE ABSTRACTS
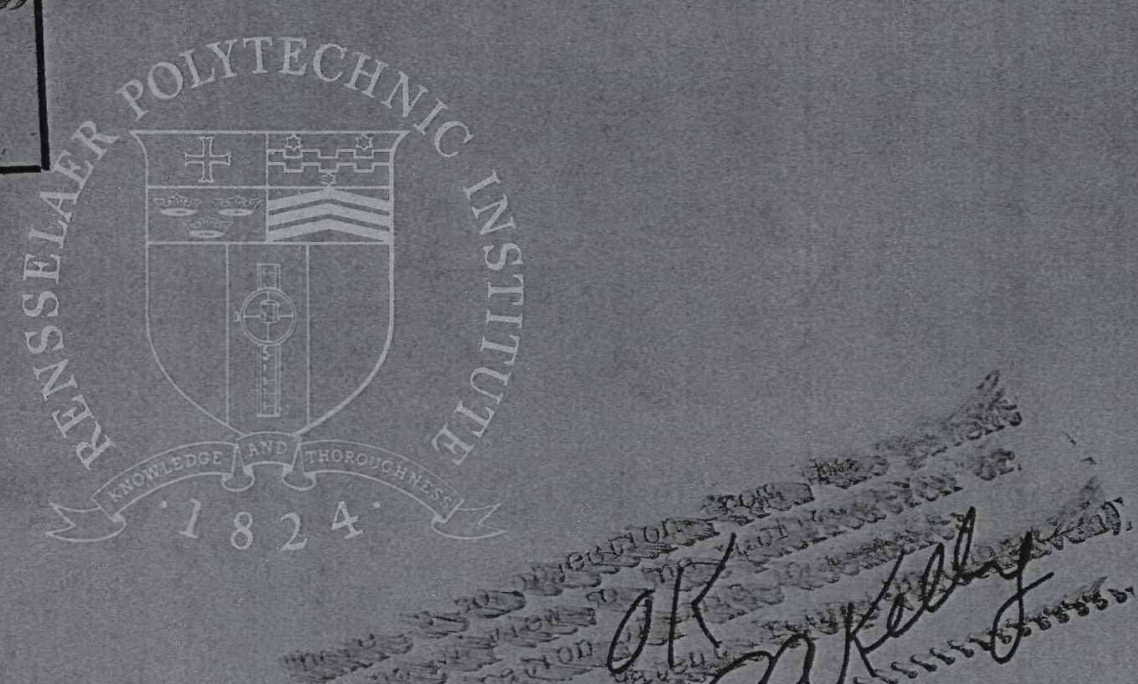


\section{DISCLAIMER}

This report was prepared as an account of work sponsored by an agency of the United States Government. Neither the United States Government nor any agency Thereof, nor any of their employees, makes any warranty, express or implied, or assumes any legal liability or responsibility for the accuracy, completeness, or usefulness of any information, apparatus, product, or process disclosed, or represents that its use would not infringe privately owned rights. Reference herein to any specific commercial product, process, or service by trade name, trademark, manufacturer, or otherwise does not necessarily constitute or imply its endorsement, recommendation, or favoring by the United States Government or any agency thereof. The views and opinions of authors expressed herein do not necessarily state or reflect those of the United States Government or any agency thereof. 


\section{DISCLAIMER}

Portions of this document may be illegible in electronic image products. Images are produced from the best available original document. 
OXIDATION CHARACTERISTICS

OF THE LANTHANIDE METALS

Technical Report

To

United States Atomic Energy Commission

Contract AT $(30-1)-2714$

N. D. Greene

F. G. Hodge

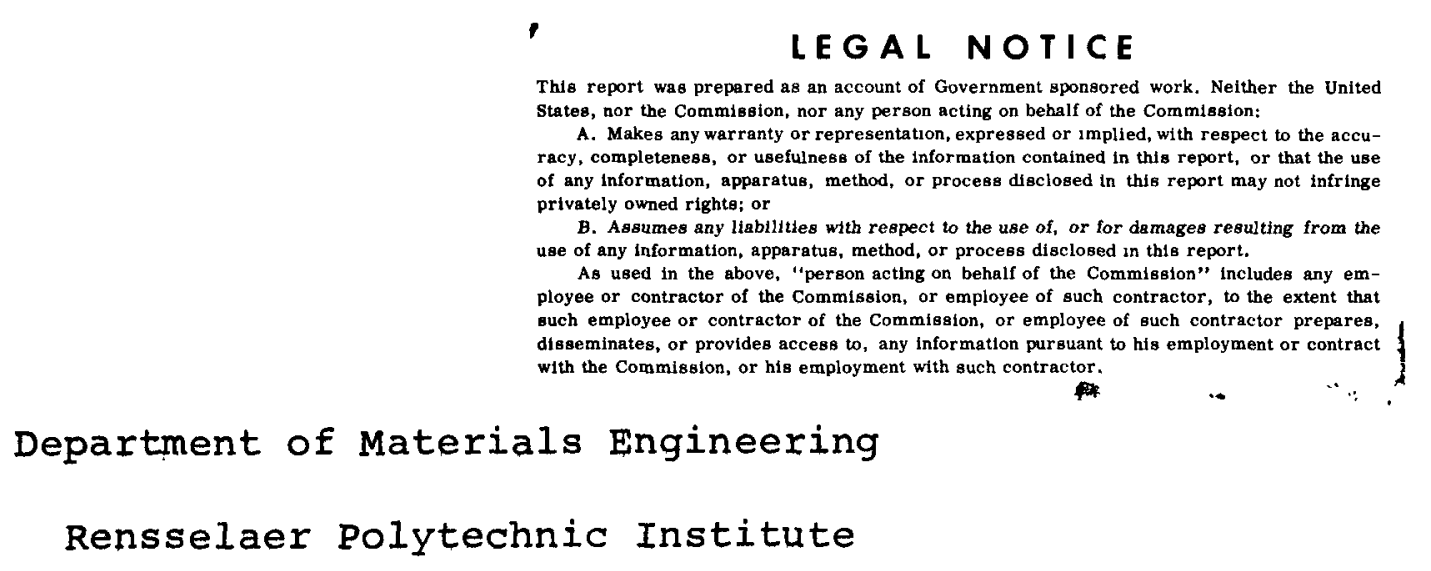

Troy, New York

March, 1966 


\section{ABS TRACT}

The oxidation rates and rate equations of the lanthanide metals have been determined in dry and moist air in the temperature range $100^{\circ}-800^{\circ} \mathrm{C}$ by precision weight gain measurements. Oxide structures have been examined by both metallographic and x-ray analyses.

The observed oxidation characteristics have been related to oxide structures and the physico-chemical properties of the rare earth metals. 


\title{
OXIDATION CHARACTERISTICS \\ OF THE LANTHANIDE METALS
}

\author{
N. D. Greene \\ F. G. Hodge* \\ Corrosion Research Laboratory \\ Department of Materials Engineering \\ Rensselaer Polytechnic Institute \\ Troy, New York \\ * Present Address: \\ Youngstown sheet and Tube Company \\ Youngstown, Ohio
}


This study is a part of a comprehensive investigation devoted to characterizing the corrosion and oxidation characteristics of the rare earth metals. The rare earths or lanthanides are the fifteen elements between and including lanthanum (atomic No. 57) and lutetium (atomic No. 71). Before considering the oxidation behaviors of the lanthanides it is helpful to briefly review some of their pertinent chemical similarities and differences.

The most common oxidation state of the rare earth metals is trivalent and three of these are particularly stable. The first is the trivalent lanthanum configuration which is the same as the extremely stable zenon configuration. The second is the half-filled 4 f configuration of trivalent gadolinium where there is one electron in each of the seven $4 \mathrm{f}$ orbitals so that further electrons are paired with one of those already present. Lastly is the trivalent lutetium configuration which has completely filled subshells. Different valence states do exist, however, and make possible the formation of several oxides which affect oxidation behavior. A11 the rare earth metals form sesquioxides, $\mathrm{M}_{2} \mathrm{O}_{3}^{(10)}$ Cerium, praseodymium, and terbium, which exhibit tetravalency, normally form higher oxides of the general compositions $\mathrm{CeO}_{2}{ }^{\prime}{ }^{(11)} \mathrm{Pr}_{6} \mathrm{O}_{11}$ and $\mathrm{Tb}_{4} \mathrm{O}_{7}$. Samarium and europium, which exhibit divalency, 
normally form lower oxides of the general composition Smo, (15)

and EuO. The oxide Tbo has been prepared but only under conditions of reduced oxygen pressure $\left(10^{-3} \mathrm{~mm} \mathrm{hg}\right)$.

The published and limited distribution literature contain a small number of papers dealing with the oxidation $(1,8,11,17-22)$ characteristics of the lanthanide metals. Quantitative data from these papers and reports are summarized in Table I. As shown, information about many metals is limited or completely lacking (e.g., europium, thulium and lutetium) and there is considerable disagreement concerning oxidation rate laws. Moisture markedly increases the oxidation rate of the rare $(1,5,8)$ earths, and sometimes causes an unusual inverse temperature effect - oxidation rate decreases with increasing temperature. Thus, the discrepancies shown in Table I may be due to variations in gas phase water content.

The scarcity of quantitative oxidation data, together with increasing technological uses of the rare earth metals, suggest that a comprehensive oxidation study of all the lanthanide metals would be desirable, and should include the effect of moisture content.

\section{EXPERIMENTAL}

Fifteen metals (lanthanum, cerium, praseodymium, neodymium, samarium, europium, gadolinium, terbium, dysprosium, holmium, erbium, thulium, ytterbium, lutetium and yttrium) were used 
in this investigation. promethium was not commercially available and yttrium was included because of its similarity (2-8)

to the lanthanide elements. Metal purities ranged from $98.0 \%$ to $99.9 \%$ with other rare earth metals as the principal impurities. Specimens were prepared by sectioning vacuum arc melted buttons into small rectangular blocks. Specimen weight was approximately 1.5 - 2.0 grams and surface area, measured to the nearest $0.001 \mathrm{~cm}^{2}$, was $2-3 \mathrm{~cm}^{2}$. Surface preparation generally consisted of polishing with $600 \mathrm{~A}$ metallographic paper under mineral oil, degreasing in the condensing vapors of boiling trichloroethylene for 5 minutes and rinsing in ethyl alcohol. The specimen was then immediately placed in a platinum holder and inserted into the oxidation test apparatus. This procedure was not applicable to lanthanum, cerium, praseodymium and europium, since slight oxidation occurred at the boiling point of trichloroethylene, $\left(80^{\circ} \mathrm{C}\right)$. These metals were prepared by polishing on $600 \mathrm{~A}$ metallographic paper in air using vinyl gloves to exclude body acids and oils; wiped with a clean paper tissue and immediately inserted in the test apparatus. Three different assemblies were used to conduct continuous weight gain oxidation measurements. Rapid oxidation rates (large weight gain) were determined with both manual and (b) automatic recording semi-micro balances possessing accuracies

(a) Mettler Balance Model Hl6

(b) Ainsworth Balance Model RV-AU-1 
of \pm 0.05 milligram. Slow oxidation rates were measured using an automatic recording balance with an accuracy of \pm 0.01 milligram. Each assembly utilized a tube furnace with a control accuracy of $\pm 2^{\circ} \mathrm{C}$ and temperature was continuously monitored with a chromel-alumel thermocouple positioned close to the test specimen.

Oxidation tests were performed in dry and moist air which was passed through the furnaces at about $80 \mathrm{cc} / \mathrm{min}$. , corresponding to a complete exchange approximately every two minutes. Dry air was prepared by passing water-pumped compressed air through a tower of 6-10 mesh Indicarb to remove $\mathrm{CO}_{2}$, through a tower of manganese dioxide to remove $\mathrm{SO}_{2}$, and through two towers of anhydrous calcium sulfate to remove water. Air with a constant water content was prepared by passing this dried and purified air through two columns of double distilled water. The dew point of the emergent gas was $21^{\circ} \mathrm{C}$, which corresponds to a water content of $17.3 \mathrm{milli-}$ grams per liter at S.T.P.

Weight gain measurements were usually conducted for periods ranging between 8 to 12 hours. Longer periods were used for some of the slowly oxidizing systems to improve accuracy. After testing, specimens were microscopically

(c) Cahn R.G. Recording Electrobalance.

(d) Trade mark for $\mathrm{CO}_{2}$ absorbing material, Fisher Chemical Company, New York. 
examined and oxide scales were subjected to conventional x-ray diffraction analysis.

\section{RESULTS}

\section{Oxidation in Dry Air}

Table II summarizes, in terms of rate constants, the results of oxidation tests in dry air. In general, these data represent the average of two or more experiments which were usually reproducible to $\pm 10 \%$. Due to the widely differing oxidation rates of the various metals, it was not possible to determine oxidation rate-time relationships at every temperature. As shown in Table II, parabolic and linear oxidation rate laws predominate. Typical parabolic behavior is shown in Figure 1, while typical linear oxidation is illustrated in Figure 2. Note that individual data points show little scatter over extended time periods. Cerium and terbium oxidize paralinearly (initially parabolic followed by linear kinetics after periods of 60-180 minutes) in certain temperature ranges. As a consequence, two rate constants are listed in Table II. The oxidation of yttrium is complex. It oxidizes according to a linear equation up to a temperature of $500^{\circ} \mathrm{C}$. At $600^{\circ} \mathrm{C}$ it initially oxidizes linearly and then demonstrates a parabolic rate law. At $700^{\circ} \mathrm{C}$ only parabolic oxidation is 
observed, while data at $800^{\circ} \mathrm{C}$ are best represented by a cubic law.

The data presented in Table II were used to calculate activation energies which are listed in Table III. In general, there is good agreement between these data and those data listed in Table I. The unusual minimum in activation energy occurring during the oxidation of gadolinium, observed by vorres, ${ }^{(20)}$ is confirmed here, although there is some discrepancy in the temperature ranges. This is probably the result of the continuous temperature increase technique employed by Vorres, which would be expected to cause positive temperature errors in his data.

with the exception of cerium, all the metals formed dark colored, adherent oxide coatings at $300^{\circ} \mathrm{C}$. X-ray diffraction analysis showed that $\mathrm{M}_{2} \mathrm{O}_{3}$ type oxides were present on every metal except cerium. Other oxides identified by $\mathrm{x}$-ray diffraction were $\mathrm{CeO}_{2}, \mathrm{Pr}_{6} \mathrm{O}_{11}, \mathrm{SmO}$ and EuO. At higher temperatures, non-adherent coatings cover these metals which oxidize linearly. At $700^{\circ} \mathrm{C}$, erbium forms a loose, powder, rose-colored oxide, identified by $x$-ray analysis to be $\mathrm{Er}_{2} \mathrm{O}_{3}$, and a loose, "cruciform" structure of $\mathrm{HO}_{2} \mathrm{O}_{3}$ covers holmium. The oxide which forms of ytterbium above $500^{\circ} \mathrm{C}$ has a cracked 
and porous appearance as shown in Figure 3.

After oxidation at $700^{\circ} \mathrm{C}$, samarium possesses, in addition to a dual oxide layer, a second phase in the metal substrate as shown in Figure 4. Similar second phases were also observed in specimens of erbium and terbium but no determinations of the composition were attempted. It is possible that these second phases are due to internal oxidation by dissolved oxygen. The change in oxidation behavior of yttrium at $600^{\circ} \mathrm{C}$ is accompanied by a change in its oxide structure. Oxides formed at $500^{\circ} \mathrm{C}$ and $600^{\circ} \mathrm{C}$ show a change in the relative intensities of the $\mathrm{Y}_{2} \mathrm{O}_{3}$ peaks.

\section{Oxidation in Moist Air.}

The effect of moisture on the oxidation of cerium is shown in Figure 5. Oxidation rate increases and the rate law changes from parabolic to linear. Similar effects are also observed with praseodymium, europium and terbium (during its initial parabolic oxidation). The rate increases observed with praseodymium and terbium are, however, much less than those obtained with cerium and europium. At $100^{\circ} \mathrm{C}$ in air containing $17.3 \mathrm{mg} \mathrm{H}_{2} \mathrm{O} /$ liter, europium oxidizes catastrophically. The surface is covered with a loose, yellow deposit of $\mathrm{Eu}(\mathrm{OH})_{2}$ identified by $\mathrm{x}$-ray analysis.

Figure 6 shows the effect of moisture on the oxidation of 
lanthanum at $300^{\circ} \mathrm{C}$. At a given temperature, oxidation rate increases, although the oxidation rate law (parabolic) is unchanged. Note the inverse temperature effect shown in Figure 6. At a constant water content, oxidation rate decreases as temperature is increased from $100^{\circ} \mathrm{C}$ to $300^{\circ} \mathrm{C}$. Figure 6 is typical of all the rare earth metals except cerium, praseodymium, europium and terbium, as noted above.

The effect of moisture on the oxidation characteristics of the rare earth metals can be summarized as follows:

1) In the presence of $17.3 \mathrm{mg}$ of water vapor per liter of dry air at standard temperature and pressure (STP), the oxidation of cerium, praseodymium, europium and terbium, transforms from parabolic to linear behavior with a corresponding increase in rate. At this moisture content, oxidation rate increases with increasing temperature.

2) In the presence of $17.3 \mathrm{mg} \mathrm{H}_{2} \mathrm{O} /$ liter of dry air at STP, the oxidation rate laws (parabolic, linear) of the other lanthanides are unchanged, although their oxidation rates are increased. At a constant water content, oxidation rate decreases with increasing temperature.

\section{DISUCSSION}

As indicated above, the lanthanides oxidize according to different oxidation laws: parabolic, linear, paralinear, cubic and catastrophic. A parabolic rate law is observed when oxidation is controlled by the diffusion of a reacting species through an oxide layer of increasing thickness. The 
rare earths which exhibit parabolic oxidation for the entire temperature range studied are lanthanum, praseodymium, neodymium, samarium, europium, gadolinium, dysprosium and lutetium. With the exceptions of praseodymium, samarium, and europium, these metals form only the $\mathrm{M}_{2} \mathrm{O}_{3}$ oxide. Praseodymium exhibits a tetravalent oxidation state in addition to the normal trivalent state, and as a result forms the oxide $\mathrm{Pr}_{6} \mathrm{O}_{11}$ in addition to the sesquioxide $\mathrm{Pr}_{2} \mathrm{O}_{3}$. The praseodymium tetravalent electronic configuration approaches the $\mathrm{La}^{3+}$ stable configuration but contains an extra $4 f$ electron and is less stable than the normal trivalent configuration. Therefore, the sesquioxide $\mathrm{Pr}_{2} \mathrm{O}_{3}$ is probably the predominate form. Samarium and europium form both monoxides and sesquioxides. The sesquioxides, because of their greater specific volumes and higher oxygen contents, tend to form separate outer layers (see Figure 4). Thus, anion or cation diffusion through an $\mathrm{M}_{2} \mathrm{O}_{3}$ type oxide appears to be the cause of parabolic oxidation among the lanthanides.

Linear oxidation behavior is the result of diffusion through a barrier of constant thickness. Holmium, erbium, thulium and ytterbium oxidize linearly at all temperatures. Ytterbium oxidizes to the sesquioxide, $\mathrm{Yb}_{2} \mathrm{O}_{3}$, which has a specific volume of 0.8 with respect to the metallic state. According to the Pilling-Bedworth rule, such oxides do not 
completely cover the metal surface which causes linear oxidation kinetics. This is supported by Figure 3, which shows that the oxide layer on ytterbium is severely cracked. Holmium, erbium and thulium have hexagonal crystal lattices possessing the lowest $c / a$ ratios of all hexagonal metals. ${ }^{(3-5)}$ Epitaxial oxide growth on these compact, metal unit cells is necessarily accompanied by very high internal stresses because of the larger specific volumes $(24)$ and lattice parameters $(5)$ of the rare earth oxides. Hence, the linear oxidation of these three lanthanides is most likely the result of oxide film rupture and/or stress-activated nucleation of their normal, large volume oxide structures.

Paralinear oxidation, first characterized by Loriers for cerium and later expanded by Haycock, is a combination of parabolic and linear rate laws and is usually associated with metals which form two oxide phases. Initially, parabolic behavior is observed due to the formation of a protective oxide layer. If this oxide transforms to a second oxide phase at a sufficient rate, a transition to linear oxidation kinetics occurs after a short time because the protective oxide layer reaches a constant thickness. Since paralinear oxidation rate depends on two competing reactions, it is usually associated with a narrow temperature region. At lower temperatures, parabolic oxidation is observed while higher temperatures yield linear oxidation kinetics. The oxidation characteristics of 
cerium and terbium (Table II) are consistent with this hypothesis. In the tetravalent state, cerium has the same stable xenon configuration as $\mathrm{La}^{+3}$ and tetravalent terbium assumes the very stable $\mathrm{Gd}^{+3}$ configuration. Both metals therefore form the dioxides, $\mathrm{CeO}_{2}$ and $\mathrm{TbO}_{2}$, in addition to the sesquioxides $\mathrm{Ce}_{2} \mathrm{O}_{3}$ and $\mathrm{Tb}_{2} \mathrm{O}_{3}$, as shown here by $\mathrm{x}$-ray examination.

Catastrophic oxidation is generally considered as a deviation from linear behavior resulting from non-isothermal conditions occurring at high reaction rates. (24). Under the conditions used in this investigation, cerium, terbium and erbium oxidized catastrophically at $300^{\circ}, 400^{\circ}$ and $700^{\circ} \mathrm{C}$, respectively. As indicated in Table II, linear oxidation rates were observed for cerium and terbium prior to the onset of accelerating catastrophic oxidation.

Typically, oxidation rate laws follow the sequence: parabolic $\rightarrow$ paralinear $\rightarrow$ linear $\rightarrow$ catastrophic, as temperature is increased. " with the exception of yttrium, all the metals investigated here oxidize according to this general rule (Table II). Yttrium is most unusual, since its oxidation kinetics follow an almost opposite sequence with

* Less reactive metals (e.g., iron) often oxidize according to a logarithmic equation at low. or ambient temperatures (24). The lanthanides, because of their high chemical activities, may possibly demonstrate logarithmic oxidation kinetics only at temperatures below ambient. 
increasing temperature: linear $\longrightarrow$ linear/parabolic $\longrightarrow$ parabolic $\longrightarrow$ cubic. The oxidation of yttrium at $900^{\circ}$ and $1400^{\circ} \mathrm{C}$ has been studiad recently by Borchardt, who concluded that its high temperature behavior is controlled by two competing reactions; solution of oxygen in the matrix metal and oxide film formation. Initially the solution rate of oxygen in yttrium exceeds the rate of oxide formation. As oxygen saturation is approached, oxide formation becomes predominate, and normal parabolic behavior is observed. The net effect of these two reactions is a weight gain-time curve which appears to be cubic, or possesses an exponent greater than two. The results of this investigation generally support the Borchardt mechanism. At temperatures below $500^{\circ} \mathrm{C}$, linear weight gain is observed indicating that oxygen solution in yttrium is the controlling reaction during the duration of the experiments. At $600^{\circ} \mathrm{C}$, oxide formation rate becomes significant, which produces the peculiar linear/parabolic characteristics followed by a parabolic rate equation at $700^{\circ} \mathrm{C}$. At $800^{\circ} \mathrm{C}$ the weight gain-time curve is most closely approximated by a cubic equation which is consistent with Borchardt's data obtained at higher temperatures. However, the actual mechanism may be more complex since there is a change in oxide structure between $500^{\circ}$ and $600^{\circ} \mathrm{C}$, as noted above under Results. 
The lanthanides oxidize more rapidly in the presence of water vapor due to the formation of less protective hydroxides. This effect becomes less pronounced at higher temperatures, since water adsorption and hydroxide formation are retarded, as discussed previousiy. ${ }^{(1,8)}$ Cerium, praseodynium, europium and terbium have multiple oxidation states, and the presence of moisture apparently promotes the formation of second oxide phases and causes a transition from parabolic to linear oxidation kinetics. For example, in the presence of moisture, europium forms the hydroxide $\mathrm{Eu}(\mathrm{OH})_{2}$ (or hydrated monoxide: Euo $\mathrm{H}_{2} \mathrm{O}$ ) in preference to the sesquioxide $\mathrm{Eu}_{2} \mathrm{O}_{3}$.

Oxidation rate equations are functions of the physical and electronic properties of oxide scales. Therefore, correlations between overall oxidation kinetics and the physical characteristics of the lanthanides would not be expected. Failure to find such correlations confirm this hypothesis. However, the initial oxidation rates of the rare earth metals should be very dependent on the physical properties of the individual metals. To verify this assumption, the initial oxidation rates of the lanthanides were calculated from weight gain-time curves measured at $300^{\circ} \mathrm{C}^{*}$ by constructing tangent The excessive oxidation rate of europium necessitated the use of data obtained at $250^{\circ} \mathrm{C}$ (see Table II). Ytterbium and lutetium oxidize too slowly to be accurately measured at $300^{\circ} \mathrm{C}$ as shown in Table II and data measured at $400^{\circ}$ and $350^{\circ} \mathrm{C}$, respectively, were used to determine initial rates. 
lines at the origin (time $=0$ ). The results are plotted as a function of atomic number in Figure 7 . Initial oxidation rate decreases continuously with atomic number except for cerium and europium. This observation is virtually identical to the aqueous corrosion characteristics of these metals,

reported previously, and shown in Figure 8. The gaseous and aqueous reactivities of the lanthanides are related to solid state bonding. Except for cerium and europium, metallic bond strength increases continuously with atomic number, as reflected by melting point, density, and atomic radii. Cerium and europium are less strongly bonded than their adjacent neighbors, and are therefore more reactive.

\section{$\underline{\text { SUMMARY }}$}

1. The oxidation characteristics of fourteen lanthanide metals and yttrium have been examined in detail in dry and moist air at temperatures between $100^{\circ}$ and $800^{\circ} \mathrm{C}$. Oxidation rates and rate equations have been determined, together with activation energies.

2. In dry air, oxidation generally proceeds according to linear or parabolic oxidation kinetics. At intermediate temperatures, cerium and terbium oxidize paralinearly, and at higher temperatures, together with erbium, they are catastrophically oxidized. Yttrium possesses unusual oxidation characteristics 
which are apparently related to oxygen solubility in the matrix metal.

3. Water vapor generally increases oxidation rates as a result of less protective hydroxide films. This effect becomes less pronounced as temperature is increased, since water adsorption is retarded.

4. Initial oxidation rates of the lanthanides are a function of metallic bonding. Strong metallic bonding decreases chemical reactivity.

\section{ACKNOWLEDGMENT}

We thank the United States Atomic Energy Commission for their financial support of this investigation. 


\section{REFERENCES}

1. L. Lee and N. D. Greene, corrosion, 20, 145t (1964).

2. T. Moeller, The Chemistry of the Lanthanides, Reinhold Publishing Corporation, New York (1963).

3. F. H. Spedding and A. H. Daane, The Rare Earths, John Wiley and Sons, Inc., New York (1961).

4. Karl A. Gschneidner, Jr., Rare Earth Alloys, D. Van Nostrand Co., Inc., Princeton, New Jersey (1960).

5. E. V. Kleber and B. Love, The Technology of Scandium, Yttrium and the Rare Earth Metals, Pergamon Press, New York (1963).

6. V. I. Vernadskgo, Rare Earth Elements (Translated from the Russian), Israel Program for Scientific Translations, Jerusalem (1960).

7. Rare Earth Research Group, Properties of the Rare Earth Metals and Compounds, Battelle Memorial Institute (1959).

8. B. Love, "Selection and Evaluation of Rare or Unusual Metals, Part III, The Metallurgy of yttrium and the Rare Earth Metals", WADC Tech. Report (March, 1959).

9. A. F. Wells, Structural Inorganic Chemistry, Oxford at the Clarendon Press (1962).

10. J. H. Westbrook, R. E. Carter, and R. C. Devries, A Survey of Oxygen Binary Systems, part I. Rare Earth Metal-oxygen Systems, General Electric Research Laboratory Report No. 61-RL-2634M., March, 1961.

11. R. Courtel and J. Loriers, Compt. Rend., 230, 735 (1950).

12. C. T. Stubblefield, H. Eick and I. Eyring, J. Am.Chem. Soc., 78, 3018 (1956). 
13. E. D. Guth and L. Eyring, J. Am. Chem. Soc., 76, 5242 (1954).

14. F. H. Ellinger and W. H. Zachariasen, J. Am. Chem. Soc., 25, 6560 (1953).

15. H. A. Eick, N. C. Baenziger and L. Eyring, J. Am. Chem. Soc., 78, 5147 (1956).

16. J. C. Achard, Compt. Rend., 224, 3059 (1957).

17. J. Loriers, Compt. Rend., 231, 522 (1950).

18. J. Loriers, Compt. Rend., 229, 437 (1949).

19. D. Cubicciotti, J. Am. Chem. Soc., 74, 1200 (1952).

20. K. S. Vorres, Ph. D. Thesis, State University of Iowa (1958).

21. H J. Borchardt, J. Inorg. Nuc1. Chem., 26, 711 (1964).

22. W. L. Phillips, Jr., J. Less-Common Metals, I, 139 (1964).

23. N. B. Pilling and R, E. Bedworth, J. Inst. Met., 29, 529 (1923).

24. O. Kubaschewski and B. E. Hopkins, Oxidation of Metals and Alloys, Second ed., Butterworth's, London (1962).

25. E. W. Haycock, J. Electrochem. Soc., 106, 771 (1959). 


\section{LIST OF FIGURES}

Figure 1. Oxidation of Lanthanum in Dry Air as a Function of Temperature (Parabolic Oxidation).

Figure 2. Oxidation of Erbium in Dry Air as a Function of Temperature (Linear Oxidation).

Figure 3. Oxide Layer Formed on Ytterbium in Dry Air at $700^{\circ} \mathrm{C}$. Vertical View at $150 \mathrm{x}$ Magnification, showing cracking.

Figure 4. Cross Section of Samarium Sample sfter Exposure to Dry Air at $700^{\circ} \mathrm{C}$. Note Double oxide Layers and oriented Precipitation in Metallic Substrate (bottom). 150x Magnification. Unetched.

Figure 5. Effect of Moisture on the Oxidation of Cerium.

Figure 6. Effect of Moisture on the Oxidation of Lanthanum.

Figure 7. Variation of Initial Oxidation Rate vs. Atomic Number.

Figure 8. Variation of Corrosion Rate vs. Atomic Number. (Data from Reference No. 1). 


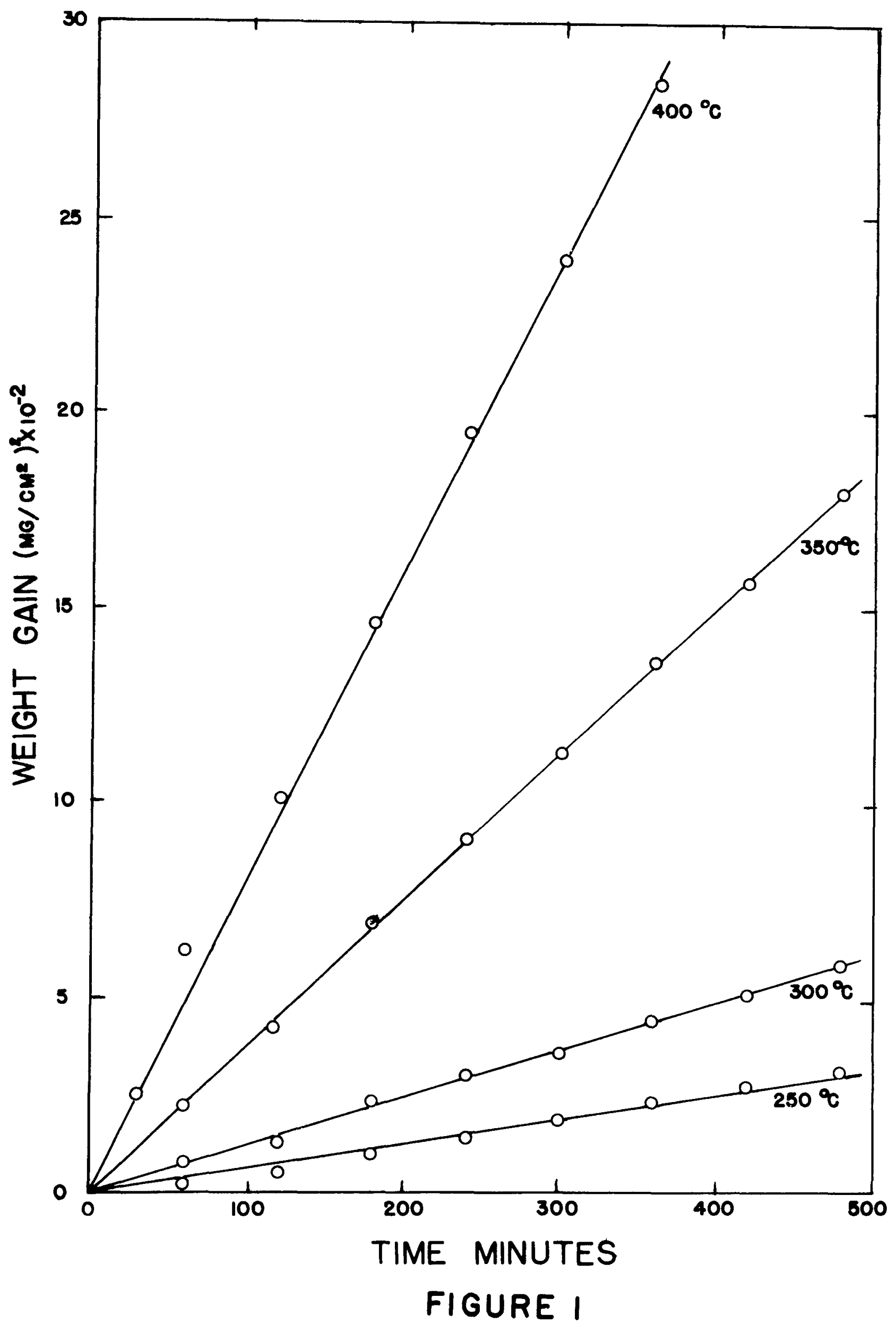




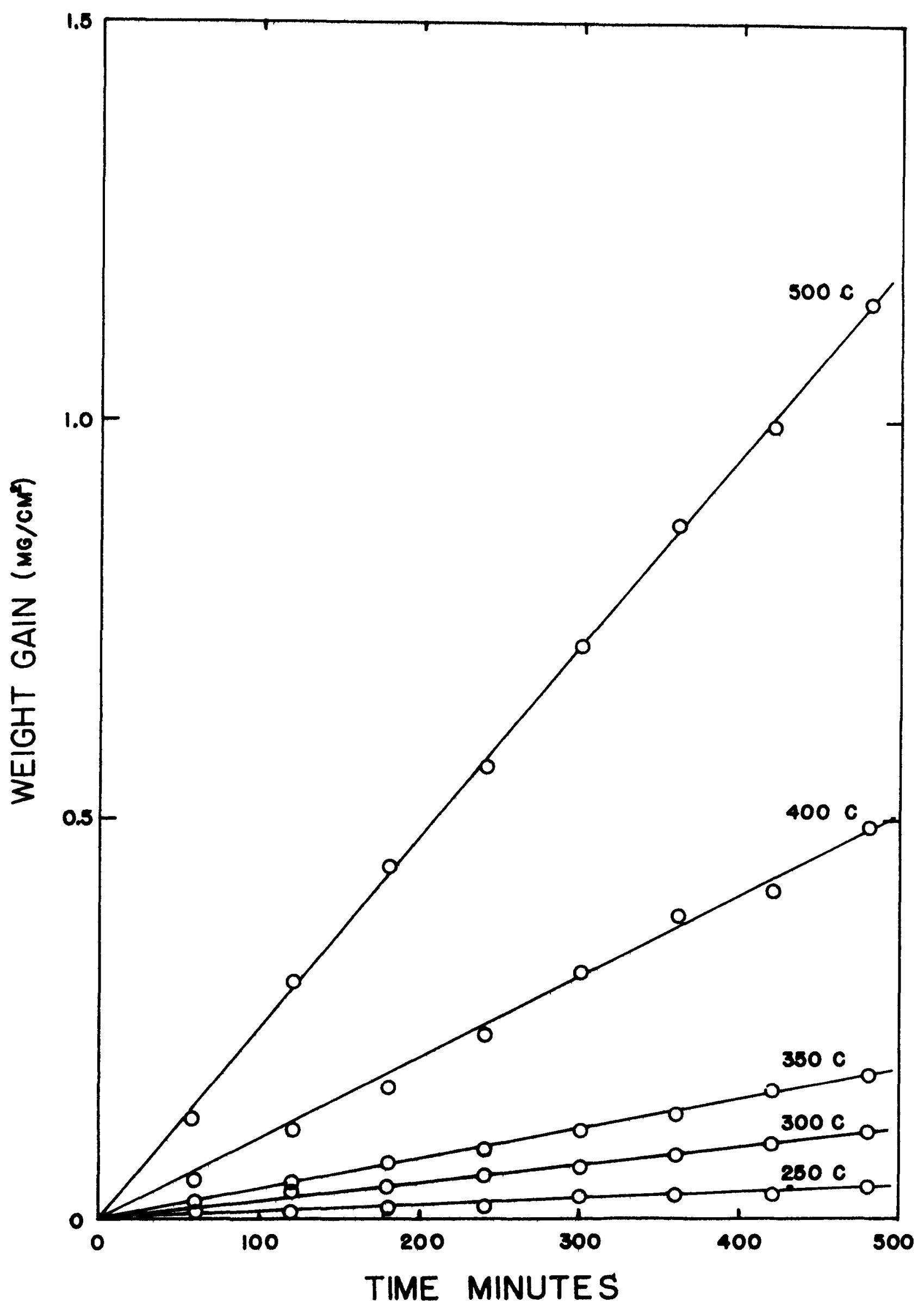

FIGURE 2 

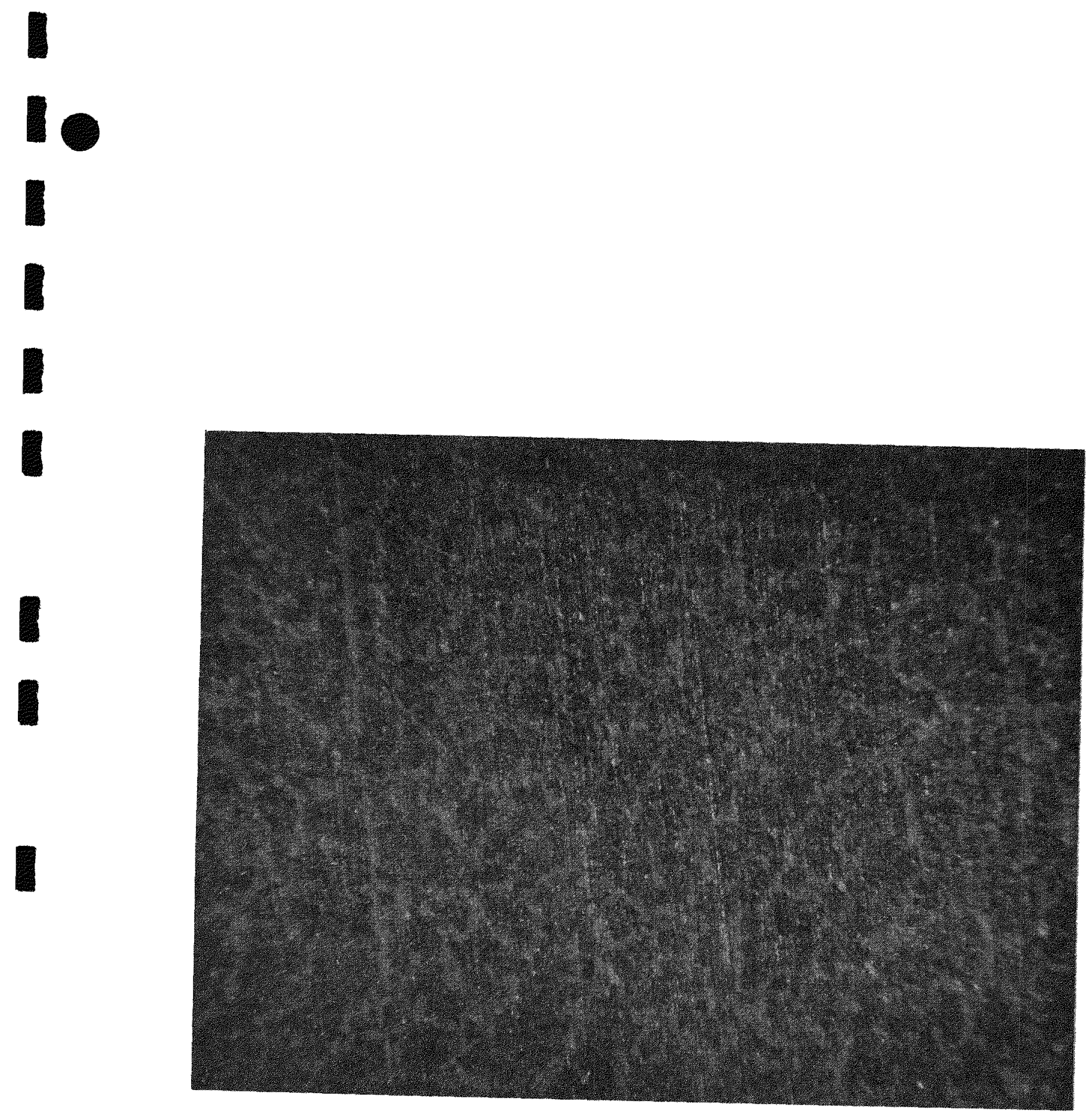

FIGURE 3 


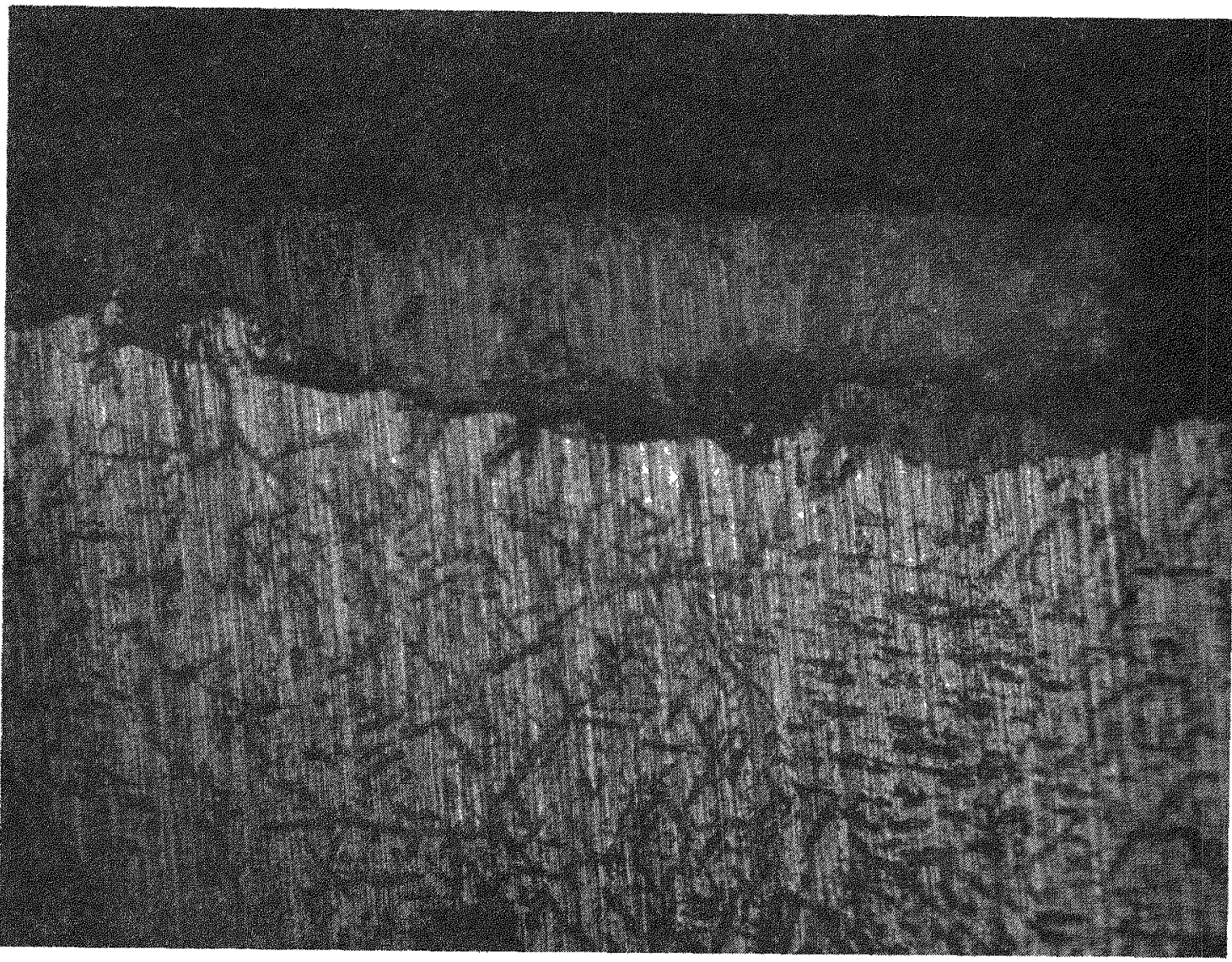

FIGURE 4 


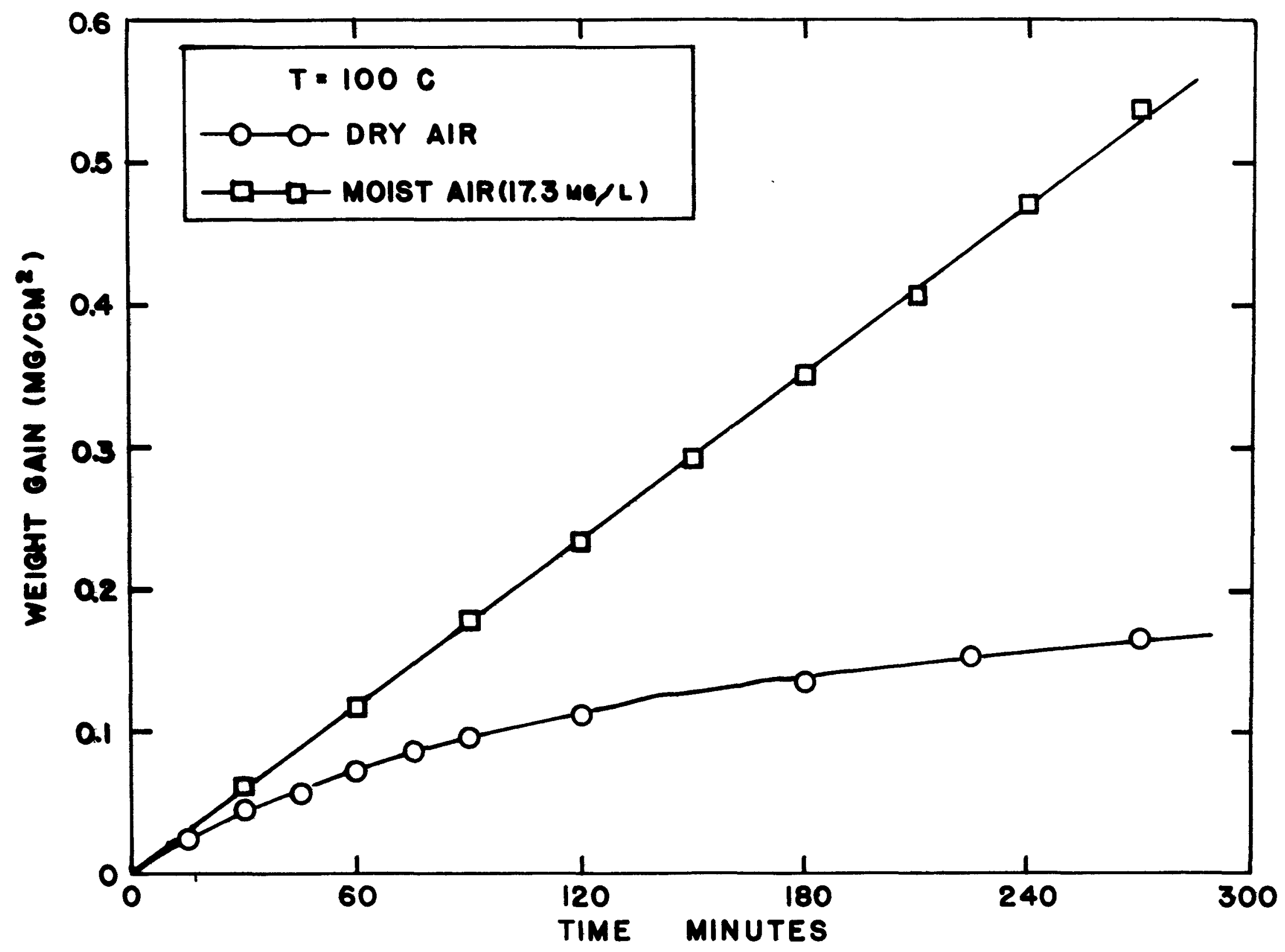

FIGURE 5 


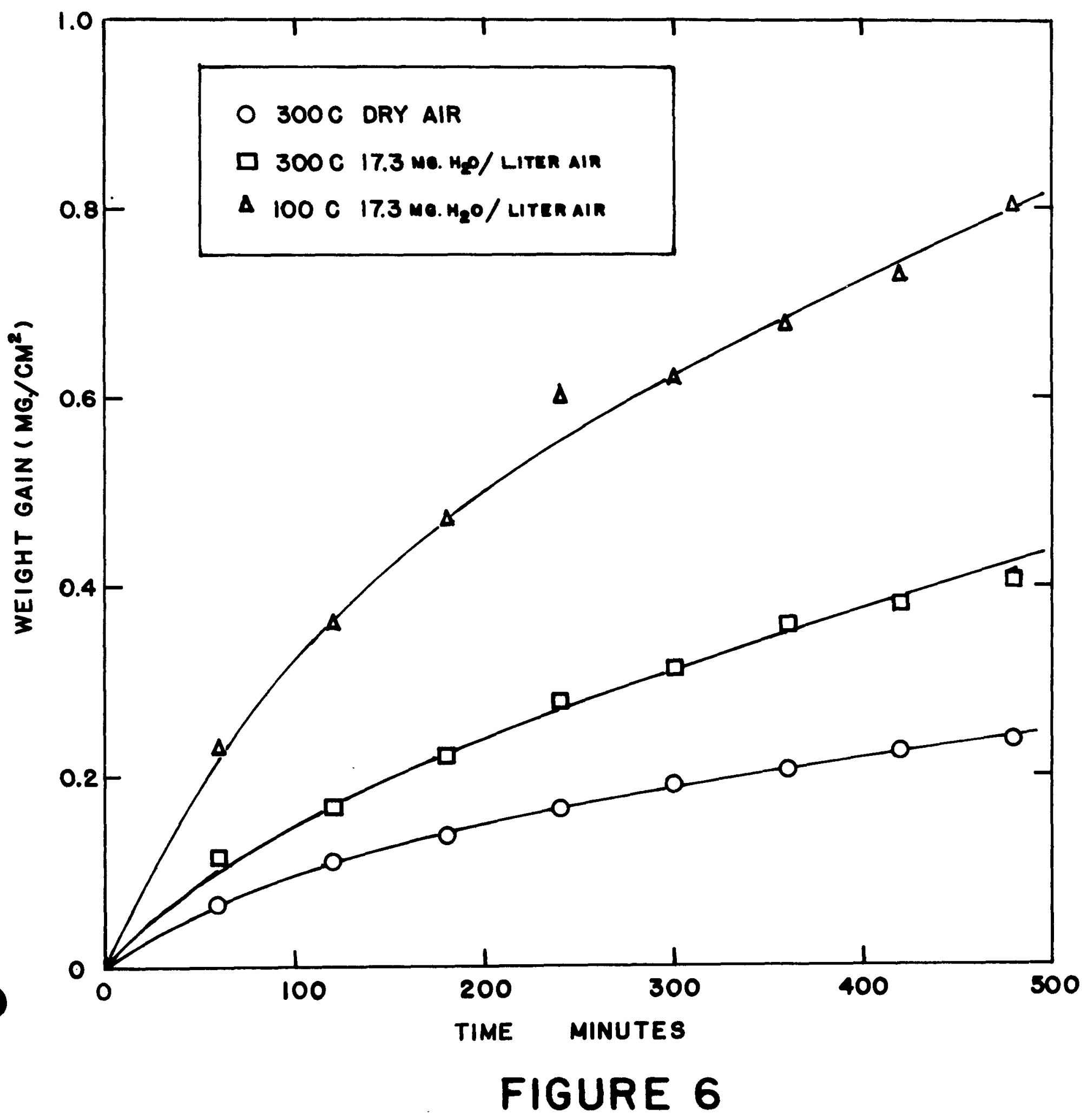




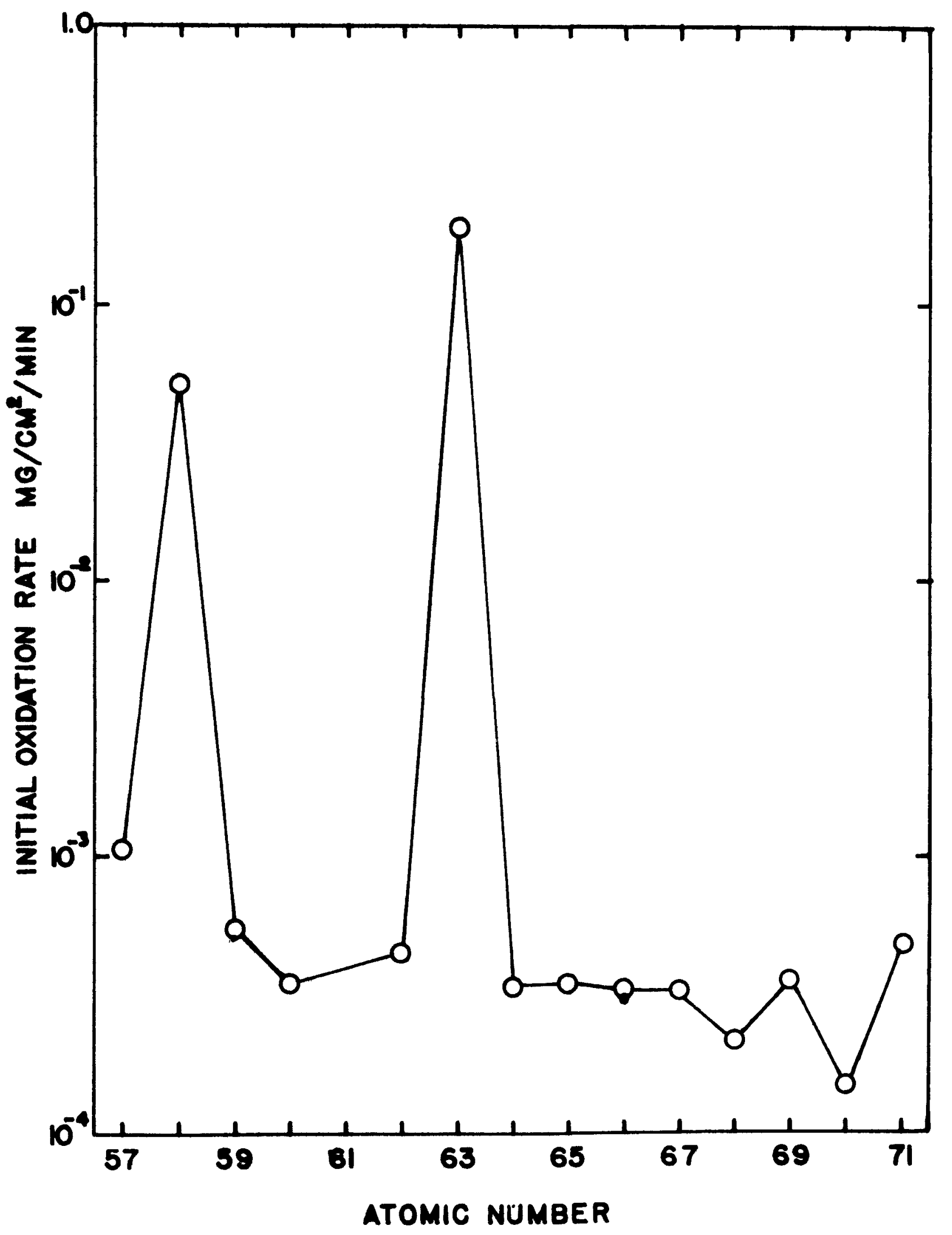

FIGURE 7 


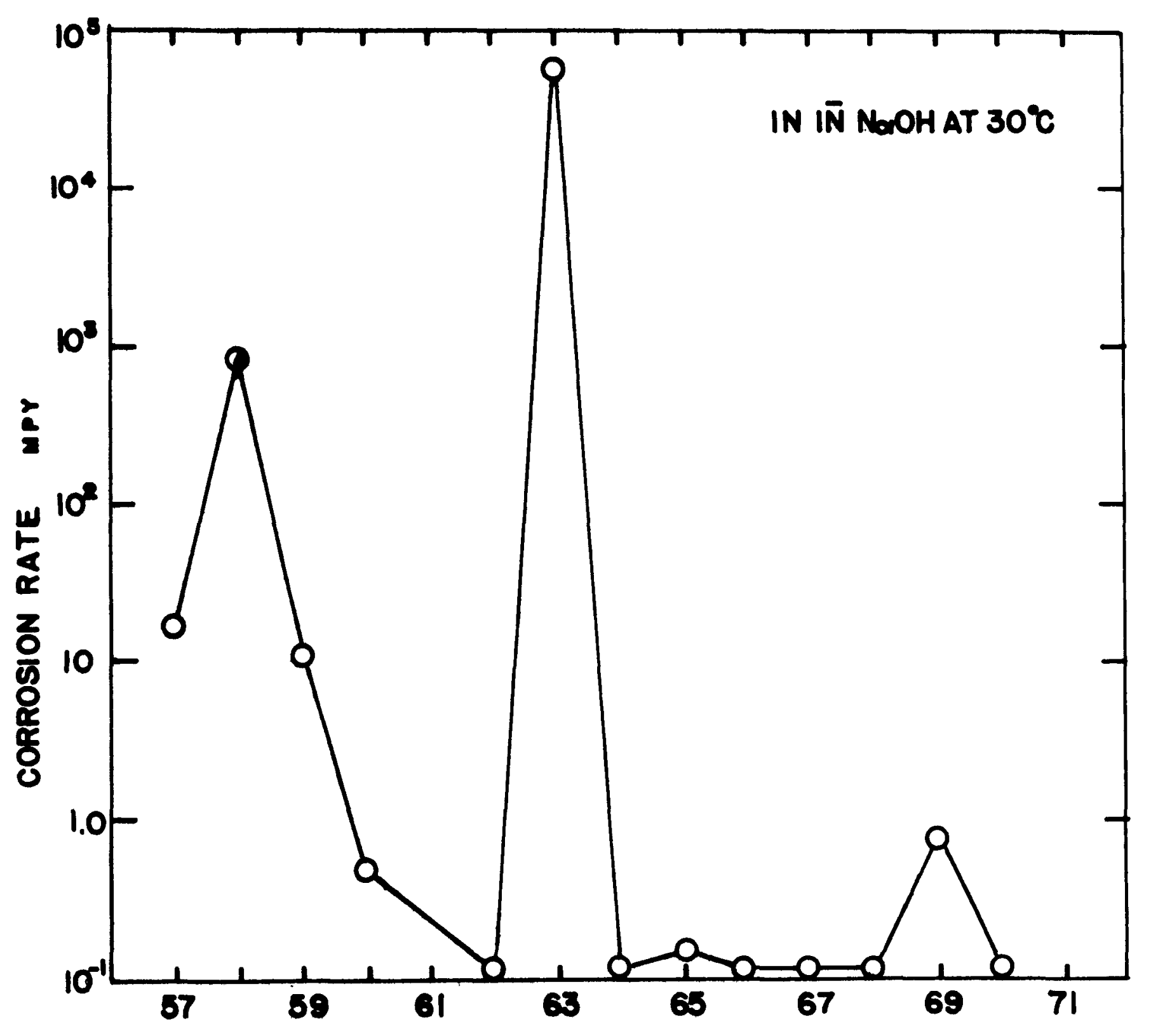

ATOMIC NUMBER

FIGURE 8 
TABLE I

SUMMARY OF PRIOR OXIDATION DATA

\begin{tabular}{|c|c|c|c|c|c|}
\hline $\begin{array}{l}\text { Ele- } \\
\text { ment }\end{array}$ & $\begin{array}{r}\text { Oxidation } \\
\text { Rate Law } \\
\end{array}$ & $\begin{array}{c}\text { Temperature } \\
\text { Range }{ }^{\circ} \mathrm{C} \\
\end{array}$ & $\begin{array}{c}\text { Reported } \\
\text { Rate Constant }\end{array}$ & $\begin{array}{l}\text { Actication } \\
\text { Energy (kcal) }\end{array}$ & Observer \\
\hline \multirow[t]{6}{*}{ La } & $P^{(1)}$ & & & & Loriers \\
\hline & $\mathbf{P}$ & $35-600$ & & & Love \\
\hline & $\mathbf{P}$ & $330-450$ & & $17 \pm 1$ & Vorres \\
\hline & $\mathrm{P}$ & $450-670$ & & $18 \pm 1$ & " \\
\hline & $P_{(2)}$ & $670-1179$ & & $28 \pm 1$ & $"$ \\
\hline & $L^{(2)}$ & $25-200$ & & & Lee \& Greene \\
\hline \multirow[t]{8}{*}{$\mathrm{Ce}$} & $P$ & $30-125$ & & 12 & Loriers \\
\hline & $P-L(3)$ & $125-200$ & & & and \\
\hline & I & $200-320$ & & 12 & Cubicciotti \\
\hline & Ignition $I$ & oove 320 & & & \\
\hline & $\mathbf{L}$ & $\begin{array}{l}600-750 \\
5 \% \text { RH Air) }\end{array}$ & $\begin{array}{r}5.0-40.0 \\
\mathrm{mg} / \mathrm{cm}^{2}-\mathrm{hr}\end{array}$ & 7.4 & Phillips \\
\hline & $P$ & $60-187$ & & $13 \pm 1$ & Vorres \\
\hline & $L$ & $187-269$ & & $15 \pm 1$ & $"$ \\
\hline & $\mathrm{L}$ & $\begin{array}{r}269-320 \\
25-200\end{array}$ & & $29 \pm 1$ & Lee \& Greene \\
\hline \multirow[t]{6}{*}{$\operatorname{Pr}$} & $(5$ & $\begin{array}{l}600-800 \\
5 \% \text { RH Air) }\end{array}$ & $\begin{array}{r}8.6-39.5 \\
\mathrm{mg} / \mathrm{cm}^{2}-\mathrm{hr}\end{array}$ & 7.4 & Phillips \\
\hline & $\mathrm{P}$ & $66-260$ & & $4 \pm 1$ & Vorres \\
\hline & $\mathrm{P}$ & $260-449$ & & $27 \pm 1$ & $"$ \\
\hline & $P$ & $449-504$ & & $68 \pm 2$ & $"$ \\
\hline & $\mathbf{P}$ & $25-200$ & & & Lee \& Greene \\
\hline & L & $200-600$ & & & Love \\
\hline \multirow[t]{6}{*}{ Nd } & I & $100-1000$ & $3.2-45.1$ & 7.4 & Phillips \\
\hline & & $5 \% \mathrm{RH}$ Air) & $\mathrm{mg} / \mathrm{cm}^{2}-\mathrm{hr}$ & & \\
\hline & $\mathbf{P}$ & elow 530 & & Variable & Vorres \\
\hline & $\mathrm{P}$ & $530-860$ & & $25 \pm 1$ & $"$ \\
\hline & $\mathbf{P}$ & $860-1150$ & & $32 \pm 2$ & $"$ \\
\hline & $\mathbf{P}$ & $35-600$ & & & Love \\
\hline
\end{tabular}

(continued) 
Table I

(continued)

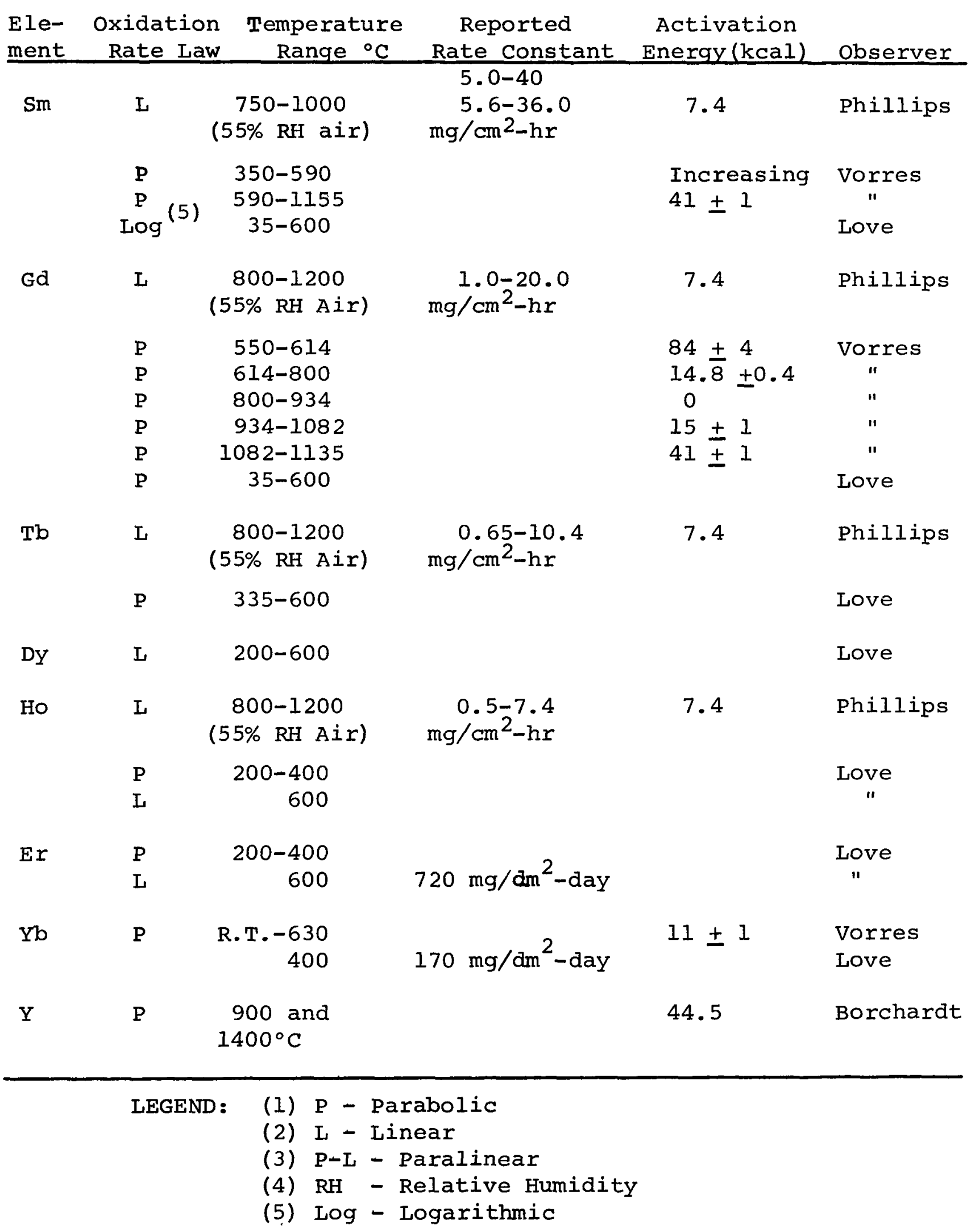


TABLE II

OXIDATION RATE CONSTANTS* FOR THE LANTHANIDE METALS

\begin{tabular}{|c|c|c|c|c|c|c|c|c|c|c|c|c|c|c|}
\hline & $100^{\circ} \mathrm{C}$ & $150^{\circ} \mathrm{C}$ & $200^{\circ} \mathrm{C}$ & $250^{\circ} \mathrm{C}$ & $300^{\circ} \mathrm{C}$ & $350^{\circ} \mathrm{C}$ & $400^{\circ} \mathrm{C}$ & $450^{\circ} \mathrm{C}$ & $500^{\circ} \mathrm{C}$ & $550^{\circ} \mathrm{C}$ & $600^{\circ} \mathrm{C}$ & $650^{\circ} \mathrm{C}$ & $700^{\circ} \mathrm{C}$ & $800^{\circ} \mathrm{C}$ \\
\hline Ia & & & & $4.8 \times 10^{-5}$ & $1.3 \times 10^{-4}$ & $3.8 \times 10^{-4}$ & $7.5 \times 10^{-4}$ & & & & & & & \\
\hline $\mathrm{Ce}$ & $1.1 \times 10^{-4}$ & & $\begin{array}{l}9.9 \times 10^{-4} \\
4.4 \times 10^{-3} \\
(L)\end{array}$ & $\begin{array}{l}1.5 \times 10^{-2} \\
1.6 \times 10^{-2} \\
\text { (L) }\end{array}$ & $\begin{array}{l}5.9 \times 10^{-2} \\
\text { (L) Catas- } \\
\text { trophlc }\end{array}$ & & & & & & & & & \\
\hline Pr & & & $2.8 \times 10^{-5}$ & $6.4 \times 10^{-5}$ & $1.1 \times 10^{-4}$ & & & & & & & & & \\
\hline $\mathrm{Nd}$ & & & & $3.1 \times 10^{-6}$ & $2.2 \times 10^{-5}$ & & $1.1 \times 10^{-4}$ & & & $1.9 \times 10^{-3}$ & & & $1.9 \times 10^{-2}$ & \\
\hline $\mathrm{Sm}$ & & & & & $8.5 \times 10^{-6}$ & & $3.0 \times 10^{-4}$ & $8.8 \times 10^{-4}$ & $3.8 \times 10^{-3}$ & & & & $3.6 \times 10^{-1}$ & \\
\hline Eu & $1.5 \times 10^{-4}$ & $1.5 \times 10^{-3}$ & $3.4 \times 10^{-2}$ & $4.0 \times 10^{-1}$ & & & & & & & & & & \\
\hline Gd & & & & & $2.2 \times 10^{-5}$ & $6.1 \times 10^{-5}$ & & $6.6 \times 10^{-5}$ & & $8.5 \times 10^{-5}$ & & & $5.2 \times 10^{-4}$ & $2.3 \times 10^{-3}$ \\
\hline $\mathrm{Tb}$ & & & & $\begin{array}{l}1.0 \times 10^{-6} \\
5.1 \times 10^{-5} \\
\text { (L) }\end{array}$ & $\begin{array}{c}3.8 \times 10^{-4} \\
\text { (L) }\end{array}$ & $\begin{array}{c}2.5 \times 10^{-3} \\
(\mathrm{~L})\end{array}$ & $\begin{array}{l}9.4 \times 10^{-3} \\
\text { (L) Catas- } \\
\text { trophic }\end{array}$ & & & & & & & \\
\hline Dy & & & & & $1.7 \times 10^{-5}$ & & & $7.0 \times 10^{-5}$ & & $1.8 \times 10^{-4}$ & & & $5.1 \times 10^{-4}$ & $2.0 \times 10^{-3}$ \\
\hline Ho & & & & & $\begin{array}{c}2.8 \times 10^{-4} \\
(\mathrm{~L})\end{array}$ & $\begin{array}{l}5.2 \times 10^{-4} \\
(\mathrm{~L})\end{array}$ & $\begin{array}{c}9.4 \times 10^{-4} \\
(\mathrm{~L})\end{array}$ & & $\begin{array}{l}1.5 \times 10^{-2} \\
(\mathrm{~L})\end{array}$ & & & & $\begin{array}{c}5.8 \times 10^{-1} \\
(\mathrm{~L})\end{array}$ & \\
\hline Er & & & & $\begin{array}{l}\text { 1. } 1 \times 10^{-4} \\
\text { (L) }\end{array}$ & $\begin{array}{c}2.6 \times 10^{-4} \\
(\mathrm{~L})\end{array}$ & $\begin{array}{c}3.8 \times 10^{-4} \\
(\mathrm{~L})\end{array}$ & $\begin{array}{l}9.0 \times 10^{-4} \\
(\mathrm{~L})\end{array}$ & & $\begin{array}{c}2.4 \times 10^{-3} \\
(\mathrm{~L})\end{array}$ & & & & $\begin{array}{l}\text { Catas- } \\
\text { troph } 1 \text { e }\end{array}$ & \\
\hline $\mathrm{Tm}$ & & & $\begin{array}{l}6.4 \times 10^{-5} \\
(\mathrm{~L})\end{array}$ & & $\begin{array}{c}3.4 \times 10^{-4} \\
(L)\end{array}$ & & $\begin{array}{c}5.0 \times 10^{-4} \\
(L)\end{array}$ & & $\begin{array}{c}6.8 \times 10^{-4} \\
(\mathrm{~L})\end{array}$ & & & & $\begin{array}{c}2.2 \times 10^{-3} \\
(\mathrm{~L})\end{array}$ & \\
\hline $\mathrm{Yb}$ & & & & & & & $\begin{array}{c}1.5 \times 10^{-4} \\
(\mathrm{~L})\end{array}$ & $\begin{array}{l}3.2 \times 10^{-4} \\
(\mathrm{~L})\end{array}$ & $\begin{array}{l}4.0 \times 10^{-4} \\
(\mathrm{~L})\end{array}$ & & $\begin{array}{c}6.3 \times 10^{-4} \\
(\mathrm{~L})\end{array}$ & $\begin{array}{c}1.5 \times 10^{-3} \\
\text { (L) }\end{array}$ & $\begin{array}{c}2.4 \times 10^{-3} \\
(\mathrm{~L})\end{array}$ & \\
\hline Lu & & & & & & $2.5 \times 10^{-5}$ & $4.4 \times 10^{-5}$ & & $1.9 \times 10^{-4}$ & & & & $1.3 \times 10^{-3}$ & \\
\hline$Y$ & & & & & $\begin{array}{c}1.0 \times 10^{-4} \\
(\mathrm{~L})\end{array}$ & $\begin{array}{l}2.0 \times 10^{-4} \\
(\mathrm{~L})\end{array}$ & $\begin{array}{l}3.9 \times 10^{-4} \\
(\mathrm{~L})\end{array}$ & & $\begin{array}{l}1.3 \times 10^{-3} \\
(\mathrm{~L})\end{array}$ & & $\begin{array}{l}1.3 \times 10^{-4} \\
1.8 \times 10^{-3} \\
(\mathrm{~L}) \\
\end{array}$ & & $3.0 \times 10^{-3}$ & $\begin{array}{l}2.4 \times 10^{-2} \\
\text { (C) }\end{array}$ \\
\hline
\end{tabular}

Paxabolic rate constants $\left(\mathrm{mg}^{2} / \mathrm{cm}^{4}-\mathrm{min}\right)$ unless denoted as Iinear (L) or cublc (C)

(L) Linear rate constant: $\mathrm{mg} / \mathrm{cm}^{2}-\mathrm{m} 1 \mathrm{n}$.

(C) cubic rate constant: $\mathrm{mg}^{3} / \mathrm{cm}^{6}-\mathrm{min}$. 
TABLE III

ACTIVATION ENERGIES FOR OXIDATION

(1)

\begin{tabular}{cccc} 
Metal & $\begin{array}{c}\text { Oxidation } \\
\text { Rate Law }\end{array}$ & $\begin{array}{c}\text { Temperature } \\
\left.\text { Range }{ }^{\circ} \mathrm{C}\right)\end{array}$ & $\begin{array}{c}\text { Activation } \\
\text { Energy(Kcal) }\end{array}$ \\
\hline La & P & $250-400$ & 13.5 \\
Ce & L & $100-300$ & 14.3 \\
Pr & P & $200-300$ & 7.9 \\
Nd & P & $250-700$ & 19.1 \\
Sm & P & $300-700$ & 30.0 \\
Eu & P & $100-250$ & 19.1 \\
Gd & P & $300-350$ & $13.9^{*}$ \\
& P & $350-550$ & $1.6^{*}$ \\
Tb & P & $550-800$ & $27.0 *$ \\
DY & L & $250-400$ & 24.1 \\
& P & $300-550$ & 9.0 \\
Ho & P & $550-800$ & $22.9 *$ \\
& L & $300-400$ & 9.6 \\
Er & L & $400-700$ & 28.6 \\
Tm & L & $250-500$ & 13.5 \\
& L & $250-300$ & $19.9 *$ \\
Yb & L & $300-700$ & 3.1 \\
Lu & L & $400-700$ & 10.9 \\
Y & P & $350-700$ & 13.5 \\
& L & $300-600$ & 10.7 \\
\hline
\end{tabular}

P: parabolic; L: linear.

(1) Except where noted by an asterisk (*), activation energies were calculated from 5 or more data points obtained at 3 or more temperatures. 